\title{
DETEKSI KEBERADAAN CITRUS VEIN PHLOEM DEGENERATION (CVPD) DENGAN TEKNIK PCR (POLYMERASE CHAIN REACTION) DI SULAWESI TENGGARA
}

\author{
Muhammad Taufik ${ }^{1}$, Andi Khaeruni ${ }^{1}$, Terry Pakki $^{1}$ \& Gianto $^{2}$
}

\begin{abstract}
ABSTARCT
Detection of ocurrence Citrus Vein Phloem Degeneration (CVPD) with PCR (Polymerase Chain Reaction) technique in Southeast Sulawesi. CVPD disease incidence in Southeast Sulawesi based on symptoms have never been reported. PCR (polymerase chain reaction) technique was utilized to detect CVPD with specific primer forward OI and reverse OI2, specific for amplication of Liberobacter asiaticum DNA. The result of the reseach indicated that $69 \%$ of orange trees in Ladongi, Kolaka District and 65\% of orange trees in Lalembuu 1, Konawe Selatan district showed the symptom. PCR technique successfully amplified DNA of bacterium L. asiaticum with the size of $1100 \mathrm{bp}$.
\end{abstract}

Key words: occurrence, PCR, CVPD, L. asiaticum

\section{PENDAHULUAN}

Jeruk merupakan komoditas buah-buahan terpenting di Indonesia setelah pisang dan mangga. Di Indonesia, beberapa jenis jeruk yang umum dibudidayakan dapat digolongkan pada beberapa kelompok seperti: jeruk Keprok, jeruk besar, jeruk Nipis dan jeruk Lemon. Jeruk Siam (Citrus nobilis var. microcarpa Hassk) termasuk salah satu kultivar Keprok yang paling banyak dibudidayakan. Sekitar $60 \%$ pasaran jeruk nasional didominasi oleh kultivar tersebut. Jeruk Siam tumbuh baik di berbagai sentra pertanaman jeruk seperti Kalimantan Selatan, Kalimantan Barat, Jawa Barat, Bali dan Sulawesi Tenggara (Dirjenhorti, 2002).

Perkembangan pertanaman jeruk Siam di Sulawesi Tenggara mengalami peningkatan sejak beberapa tahun belakang ini. Pada akhir tahun 2003, jumlah tanaman jeruk tercatat lebih dari 1,5 juta pohon (BPTPH, 2004). Menurut data terakhir dari Balai Proteksi Tanaman Pangan dan Hortikultura (2007) jumlah pohon jeruk per kabupaten adalah Konawe (37.691 pohon), Konawe Selatan (1.045.743 pohon), Kolaka (724.381 pohon), Buton (241.110 pohon) dan Muna (424.080) sehingga secara keseluruhan telah mencapai lebih dari 2.300.000 pohon atau sekitar 2500 ha. Adanya ekstensifikasi yang intensif telah memberi dampak terhadap peningkatan pendapatan petani di Sulawesi Tenggara khususnya petani jeruk. Sehingga tidaklah mengherankan jika saat ini Sulawesi Tenggara telah menjadi penyangga nasional untuk memenuhi kebutuhan jeruk di dalam negeri. Namun demikian, dalam hal membudidayakannya, seperti juga membudidayakan tanaman lain, terdapat kendala dan ancaman yang sangat serius yaitu serangan penyakit CVPD (Citrus Vein Phloem Degeneration). Penyakit CVPD disebabkan oleh patogen bakteri (Liberobacter asiaticum) yang bergram negatif (Garnier et al., 2000). Sebelumnya penyebab penyakit CVPD disebut sebagai Bacterial Like Organism (BLO). Di lapang, CVPD ditularkan oleh serangga vektor yaitu Diaphorina citri Kuwayama. Selain sebagai vektor $D$. citri juga dapat berperan sebagai hama (Hoy \& Nguyen, 1998; Mead, 2006).

Penularan penyakit CVPD dapat juga terjadi melalui bibit jeruk baik yang diperbanyak secara grafting maupun dengan mata tempel. Menurut beberapa catatan penularan dengan mata tempel lebih penting dibandingkan dengan penyambungan. Di Indonesia, CVPD menyerang hampir di seluruh propinsi. Serangan di Tulungagung sampai $62,34 \%$ dan Bali Utara sampai

\footnotetext{
1 Program Studi Ilmu Hama dan Penyakit Tumbuhan, Fakultas Pertanian, Universitas Haluoleo,

Jl. Manunggal BTN Wirabuana Blok L2 No. 18 Anduonohu Kendari Sulawesi Tenggara 93231 Kendari. E-mail : taufix24@yahoo.com

2 Departemen Proteksi Tanaman, Fakultas Pertanian, Institut Pertanian Bogor,

Jl. Kamper Kampus Darmaga Bogor 16680
} 
$60 \%$ dengan kerugian mencapai puluhan milyar rupiah per tahun (Wirawan et al., 2004). Saat ini, di Sulawesi Selatan, yaitu di Kabupaten Jeneponto, Kabupaten Sidrap (Asaad, 2001), Kabupaten Luwu Utara, Malangke (Asaad et al., 2004), telah teridentifikasi adanya CVPD dengan menggunakan teknik PCR (Polymerase Chain Reaction) dan menyebabkan kerugian yang sangat nyata yaitu menurunnya produksi jeruk daerah tersebut. Berdasarkan laporan Dinas Pertanian Luwu Utara tahun (2003) luas pertanaman jeruk yang terinfeksi CVPD di Kecamatan Malangke Barat dan Malangke masingmasing 119,5 ha dan 104,2 ha. Pergerakan bahan tanaman dari daerah tersebut kurang terpantau sehingga peluang ancaman serangan CVPD sangat terbuka di Sulawesi Tenggara, mengingat kedekatan kedua wilayah tersebut. Namun demikian belum pernah dilaporkan adanya penyakit CVPD di Sulawesi Tenggara.

Teknik PCR yang sangat sensitif dan dapat diandalkan untuk mendeteksi bakteri CVPD meskipun konsentrasinya sangat rendah di dalam jaringan tanaman (Jagoueix et al., 1996). Beberapa peneliti telah berhasil menggunakan teknik tersebut dengan hasil yang sangat sensitif, akurasi yang tinggi dan cepat (Triwiratno et al., 1999; Subandiyah et al., 2000; Bove \& Garnier, 1997). Teknik PCR menggunakan sepasang primer spesifik dari sekuen DNA bakteri CVPD. Primer tersebut sangat baik digunakan untuk mendeteksi serangan penyakit CVPD pada jeruk, dengan menggunakan primer tersebut maka hanya sekuen sekuen 16S rDNA dari bakteri CVPD, L. asiaticum, yang teramplifikasi. Sementara sekuen 16S rDNA dari bakteri lain, atau dari mitokondria dan khloroplas tanaman jeruk tidak teramplifikasi, yang terdeteksi hanya CVPD. Tujuan penelitian ini adalah melakukan survei kejadian penyakit dan deteksi CVPD di Sulawesi Tenggara menggunakan teknik PCR.

\section{METODE PENELITIAN}

Penelitian dilakukan dari bulan Mei sampai dengan Agustus 2009. Pengambilan sampel jeruk yang bergejala CVPD di sentra-sentra pertanaman jeruk di Sulawesi Tenggara, seperti di Kabupaten Kolaka, Konawe Selatan, dan Konawe, selanjutnya deteksi dengan teknik PCR di Laboratorium Virologi Tumbuhan, Departemen Proteksi Tanaman, Fakultas Pertanian, Institut Pertanian Bogor, Bogor.

\section{Survei Kejadian Penyakit CVPD}

Pengamatan kejadian penyakit berdasarkan gejala khas CVPD. Kejadian penyakit dihitung dengan menggunakan rumus: Jumlah tanaman yang menunjukkan gejala khas CVPD/ Jumlah tanaman yang diamati dikali $100 \%$. Jumlah sampel yang diamati kurang lebih $10 \%$ dari populasi tanaman jeruk yang ada dalam satu kebun yang diamati. Daun jeruk yang diambil dari satu pohon jeruk yang telah menunjukkan gejala klorosis di antara tulang-tulang daun, sementara tulang daun masih berwarna hijau gelap (gejala khas CVPD). Sampel yang diambil dilakukan secara acak pada bagian atas, tengah dan bawah pohon secara acak baik yang bergejala maupun tidak bergejala kemudian dikomposit dan dijadikan satu untuk dianalisis PCR. Sampel daun jeruk (tangkai tunas muda) yang akan dideteksi dengan teknik PCR dimasukkan ke dalam kantong plastik bening. Tangkai jeruk terlebih dahulu dibalut dengan kapas yang telah dibasahi dengan akuades dan diikat dengan karet gelang agar tidak mudah lepas, kemudian dimasukkan ke dalam kotak pendingin.

\section{Analisis PCR}

Ekstraksi DNA genomik. Analisis PCR dilakukan berdasarkan metode Su \& Hung (2001) yaitu daun-daun dan cabang-cabang tanaman dikumpulkan dan ibu tulang daun dan kulit cabang dibuang. Sebanyak 3 sampai 5 helai daun jeruk dipotong kecil-kecil, kemudian disimpan dalam mortar selanjutnya disimpan selama 30 menit dalam lemari pendingin $-80^{\circ} \mathrm{C}$. Bahan tersebut dihancurkan di dalam mortar dan pistil yang diberi nitrogen cair sampai berbentuk tepung halus dan disuspensi dalam $0,5 \mathrm{ml}$ bufer ekstraksi yang mengandung 2\% CTAB (w/v), $100 \mathrm{mM}$ Tris- $\mathrm{HCl} \mathrm{pH}$ $8,0,20 \mathrm{mM}$ EDTA, $1,4 \mathrm{M} \mathrm{NaCl}$, dan $1 \%$ Mercaptoetanol. Suspensi ini dimasukkan dalam tabung mikro $(1,5 \mathrm{ml})$ dan diinkubasi pada suhu $65^{\circ} \mathrm{C}$ selama 10 menit. Selanjutnya dilakukan sentrifugasi pada $5000 \mathrm{rpm}$ selama 5 menit dan supernatan yang dihasilkan dipindahkan ke dalam tabung mikro baru. Campuran khloroform : isoamylalkohol (24:1) ditambahkan ke dalam supernatan dengan volume yang sama, kemudian divorteks dan disentrifugasi pada $15.000 \mathrm{rpm}$ selama 5 menit. Supernatan sebanyak $90 \mathrm{ml}$ dipindahkan ke dalam tabung baru dan ditambahkan $10 \mathrm{ml} \mathrm{NaOAc}(\mathrm{pH} \mathrm{5,2)}$ dan $200 \mathrm{ml}$ etanol absolut dingin $\left(-20^{\circ} \mathrm{C}\right)$ kemudian diinkubasi pada suhu $-20^{\circ} \mathrm{C}$ selama 30 menit. Supernatan sebanyak $90 \mathrm{ml}$ dipindahkan ke dalam tabung baru dan ditambahkan $10 \mathrm{ml} \mathrm{NaOAc}(\mathrm{pH} 5$,2) dan $200 \mathrm{ml}$ etanol absolut dingin $\left(-20^{\circ} \mathrm{C}\right)$ kemudian diinkubasi pada suhu $-20^{\circ} \mathrm{C}$ selama 30 menit. Supernatan dibuang setelah disentrifugasi $11.500 \mathrm{rpm}$ selama 15 menit. Pelet DNA yang dihasilkan dicuci dengan etanol dingin $70 \%\left(-20^{\circ} \mathrm{C}\right)$ dan disentrifugasi pada $11.500 \mathrm{rpm}$ selama 15 selama 2 menit. Etanol dibuang, kemudian pelet dikeringkan. Pelet 
tersebut kemudian disuspensi dalam $50 \mathrm{ml}$ bufer TE (10 $\mathrm{mM}$ Tris- $\mathrm{HCl} \mathrm{pH} 8,0$ ).

Amplifikasi DNA. DNA hasil isolasi diamplifikasi dengan teknik PCR. Primer untuk deteksi CVPD(SBS Genetech Co.Ltd.China). Untuk master mix-nya memakai MegaMix-Royal (MMR), konsentrasinya 2x (Microzone Ltd.United Kingdom). Untuk membuat volume akhir $25 \mu \mathrm{l}$ untuk PCR sebagai berikut : MMR 12,5 $\mu 1$, primer 1 1,0 $\mu \mathrm{l}(10-20 \mathrm{pmol} / \mathrm{ul})$, primer $21,0 \mu 1 \quad(10-20 \mathrm{pmol} / \mathrm{ul})$, template $1,0 \mu \mathrm{l}$ dan aquabides $9,5 \mu 1$. Sekuen primer yang digunakan sesuai yang telah dikonstruksi oleh (Jagoueix et al., 1994) yaitu: Primer forward (OI) terdiri atas 23 nukleotida dengan susunan : 5' GCG CGT ATG CAATAC GAG CGG CA 3' Primer reverse (OI2c) terdiri atas 22 nukleotida dengan susunan sbb : 5' GCC TCG CGA CTT CGC AAC CCA T 3' (SBS Genetech Co.Ltd. China.). Menggunakan primer tersebut ukuran DNA yang teramplifikasi adalah sekitar 1100 pasang basa. Program PCR yang digunakan adalah program PCR menggunakan mesin MyCycler BioRad (USA) untuk denaturasi pada suhu $95^{\circ} \mathrm{C} 5$ menit $1 \mathrm{X}, 94^{\circ} \mathrm{C} 1$ menit, untuk annealing $55^{\circ} \mathrm{C} 30$ detik, dan ektensi $72^{\circ} \mathrm{C} 1$ menit (siklus 94 - 55 - 72 sebanyak $40 \mathrm{X}$ ), $72^{\circ} \mathrm{C} 5$ menit $1 \mathrm{X}, 4$ ${ }^{\circ} \mathrm{C}$ Hold tak terhingga.

Visualisasi hasil PCR. Fragmen DNA hasil amplifikasi PCR dielektroforesis pada gel agarosa $1 \%$. Bufer untuk elektroforesis digunakan TAE bufer yang mengandung 0,04 M Tris-asetat, 0,001 M EDTA, pH 8,0). Sebanyak 3-5 ml produk PCR dimasukkan ke dalam sumuran dan dielektroforesis selama 30 menit pada 100 Volt.

\section{HASIL DAN PEMBAHASAN}

\section{Survei kejadian penyakit CVPD di Sulawesi Tenggara}

Berdasarkan survei yang telah dilakukan pada tanaman jeruk di beberapa kecamatan sentra penanaman jeruk di Sulawesi Tenggara seperti Kecamatan Lalembuu, Kabupaten Konawe Selatan, Kecamatan Ladongi, Kabupaten Kolaka, dan Kecamatan Abuki, Kabupaten Konawe, berhasil ditemukan gejala khas CVPD yang pada tanaman jeruk (Gambar 1). Tanaman yang menunjukkan gejala selanjutnya dikumpulkan untuk dideteksi keberadaan CVPD dengan menggunakan teknik PCR (polymerase chain reaction). Selanjutnya dilakukan penghitungan kejadian penyakit CVPD di daerah-daerah tersebut.
Hasil pengamatan kejadian penyakit mencapai 5-69\% tanaman yang menunjukkan gejala CVPD (Tabel 1).

Berdasarkan hasil pengamatan gejala di lapang, dapat dilaporkan bahwa infestasi bakteri penyebab penyakit CVPD, L. asiaticum di sentra pertanaman jeruk di Sulawesi Tenggara berkisar antara 5\% sampai dengan 69\%. Dan secara umum dapat dicatat bahwa rata-rata tanaman bergejala telah melebihi angka 50\% khususnya di Kabupaten Kolaka dan Konawe. Tanaman yang bergejala tersebut telah memberikan gambaran untuk sesegera mungkin melakukan tindakan pengendalian. Dwiastuti et al. (2003) telah melaporkan bahwa sebanyak $86,25 \%$ tanaman jeruk asal 10 kabupaten di Jawa Timur yang diambil sampelnya telah terinfeksi CVPD. Olehnya itu dapat diduga bahwa jika tidak dilakukan tindakan pengendalian maka sebaran penyakit CVPD akan semakin cepat, karena penyakit ini dapat ditularkan oleh serangga vektor Diaphorina citri atau melalui perbanyakan vegetatif.

Pertanaman yang disurvei dan diambil sampelnya belum ditemukan keberadaan vektor CVPD (D. citri). Diduga penyakit menyebar melalui materi atau bahan tanaman yang digunakan oleh petani jeruk sebagai sumber bibit. Hal ini diperkuat oleh adanya tanaman jeruk di Kecamatan Tinanggea yang baru berumur kurang lebih 2 tahun telah menunjukkan gejala CVPD. Dikhawatirkan bibit yang disalurkan dan ditanam oleh petani berasal dari bibit asalan. Telah dilaporkan keberadaan bibit jeruk asal Malangke, Sulawesi Selatan yang telah diketahui bahwa daerah tersebut telah terinvestasi oleh CVPD, oleh karena itu, perlu dilakukan penataan distrubusi bibit jeruk atau penyediaan bibit jeruk asal tetua yang bebas CVPD. Di samping itu perlu dilakukan tindakan eradikasi pada tanaman yang sudah tidak produktif, sedangkan pada tanaman yang dimungkinkan untuk dikendalikan tetap dipelihara dengan menyemprotkan mikronutrien besi $(\mathrm{Fe})$ dan zinc $(\mathrm{Zn})$. Aubert (1992) menemukan bahwa analisa nutrien daun bergejala CVPD menunjukkan kandungan zinc $70 \%$ lebih dibandingkan dengan daun yang sehat, selain kandungan mangan yang juga rendah.

\section{Deteksi CVPD}

Deteksi CVPD dengan menggunakan primer OI1 dan primer OI2c yang selanjutnya di amplifikasi dalam mesin PCR (Biorad), yang divisualisasi dengan elektroforesis menggunakan larutan TBE 1 pada gel $1,5 \%$ (Biorad) berhasil mendeteksi keberadaan CVPD di dalam daun tanaman jeruk sampel asal Kecamatan Konda, Kabupaten Konawe Selatan dengan ukuran 1100 bp (Gambar 2). Hasil ini diyakini positif karena proses 


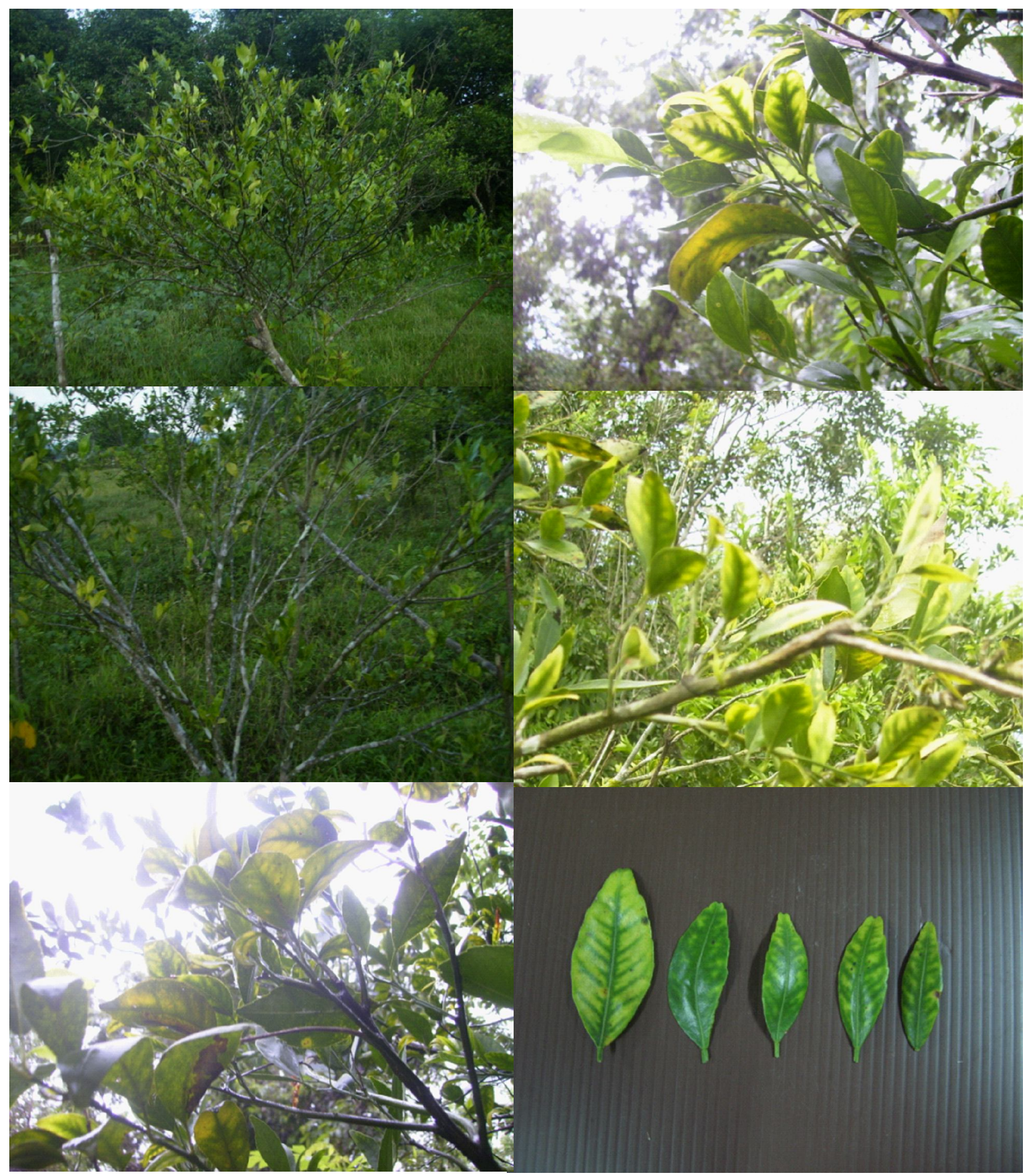

Gambar 1. Gejala khas CVPD yang menunjukkan adanya penebalan tulang daun (tetap hijau) sementara antar tulang mengalami klorosis atau menguning (Foto diambil dari beberapa lokasi kebun jeruk di Sulawesi Tenggara, 2007) 
Tabel 1. Jumlah tanaman yang menunjukkan gejala CVPD di tiga kabupaten di Sulawesi Tenggara

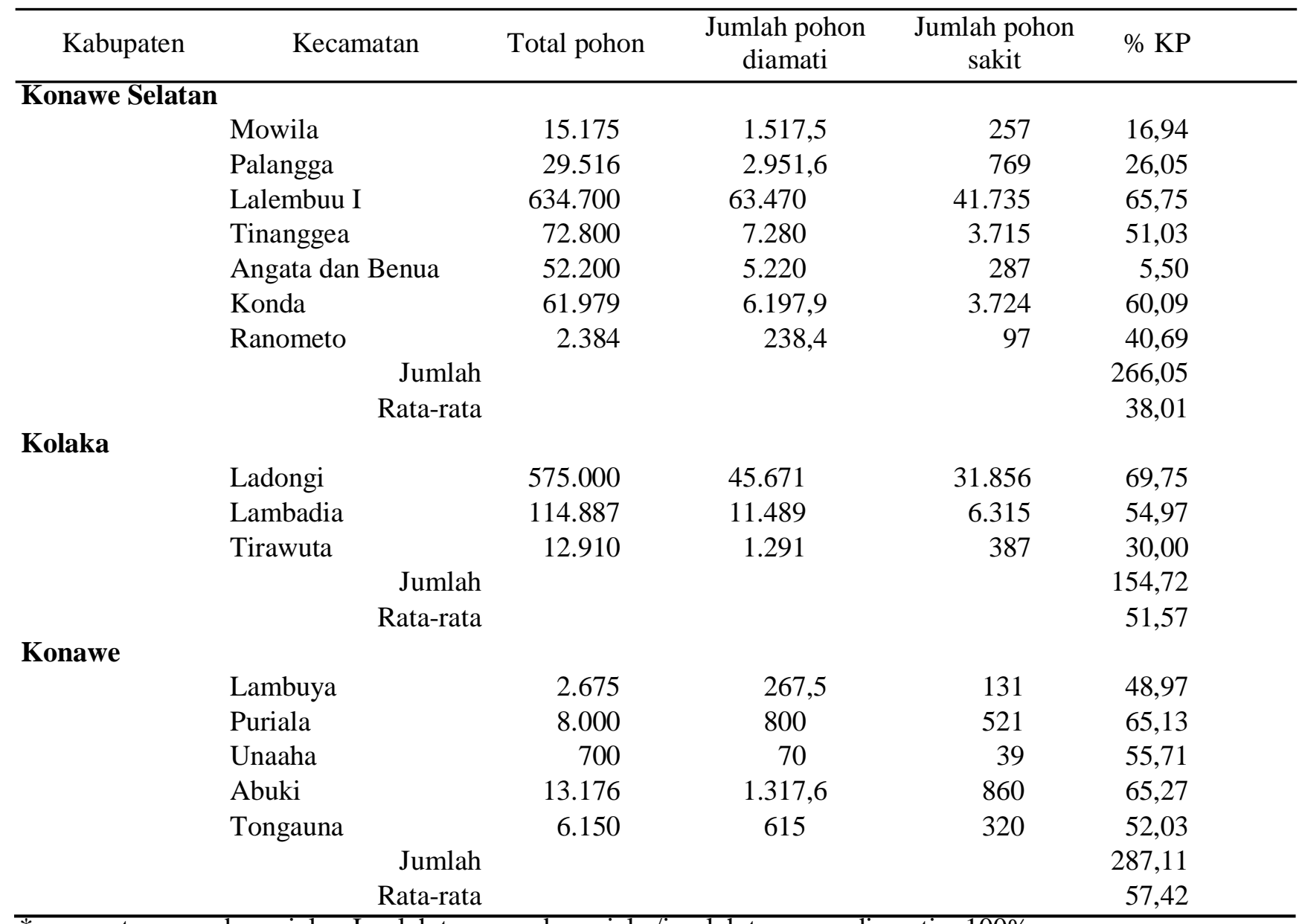

* persen tanaman bergejala : Jumlah tanaman bergejala /jumlah tanaman diamati x 100\%

PCR dilakukan dua kali pada sampel-sampel yang positif yaitu pada kolom 5 dan 8 , sementara kolom lainnya adalah sampel-sampel jeruk yang negatif setelah dirunning pada gel elektroforesis. Informasi ini menjadi penting karena merupakan informasi yang pertama bahwa CVPD juga telah terinfestasi pada tanamantanaman jeruk di Sulawesi Tenggara. Meskipun perlu dilakukan uji lanjutan pada sentra-sentra pertanaman jeruk lainnya. Namun diyakini bahwa tanaman yang telah menunjukkan gejala CVPD juga telah terinfeksi oleh bakteri penyebab penyakit CVPD yang disebabkan oleh bakteri $L$. asiaticum.

Berdasarkan hasil visualisasi PCR (Gambar 2) menunjukkan ada dua sampel yang positif terinfeksi yang terbukti positif terinfeksi bakteri penyebab penyakit CVPD (L. asiaticum). Hasil telah cukup memberikan informasi penting bahwa penyakit CVPD telah ada di Sulawesi Tenggara. Informasi keberadaan CVPD belum pernah dilaporkan sebelumnya, sementara populasi tanaman jeruk yang cukup tinggi sehingga keberadaan CVPD dapat menjadi ancaman bagi pertanaman jeruk di Sulawesi Tenggara di masa datang. Meskipun demikian beberapa sampel belum menunjukkan reaksi positif diduga konsentrasi bakteri di dalam jaringan tanaman tidak merata. Hal ini telah dijelaskan oleh Wirawan et al. (2004) bahwa penyebaran bakteri $L$. asiaticum di dalam jaringan tanaman jeruk tidak merata.

Deteksi CVPD pada daun yang menunjukkan gejala belang-belang kuning tidak teratur dan tulang daun tetap hijau asal Kecamatan Konda menghasilkan pita hasil elektroforesis setelah di PCR menggunakan primer forward (OI) Primer reverse (OI2c) dengan ukuran fragment DNA sekitar $1100 \mathrm{bp}$. Hal ini berarti telah ditemukan DNA bakteri penyebab penyakit CVPD yaitu L.asiaticum asal sampel daun jeruk yang menunjukkan gejala CVPD di Kecamatan Konda, Kabupaten Konawe Selatan. Hal ini telah dilaporkan oleh Jagoeuix et al. (1994) bahwa sekuen spesifik pada fragmen 16S rDNA 


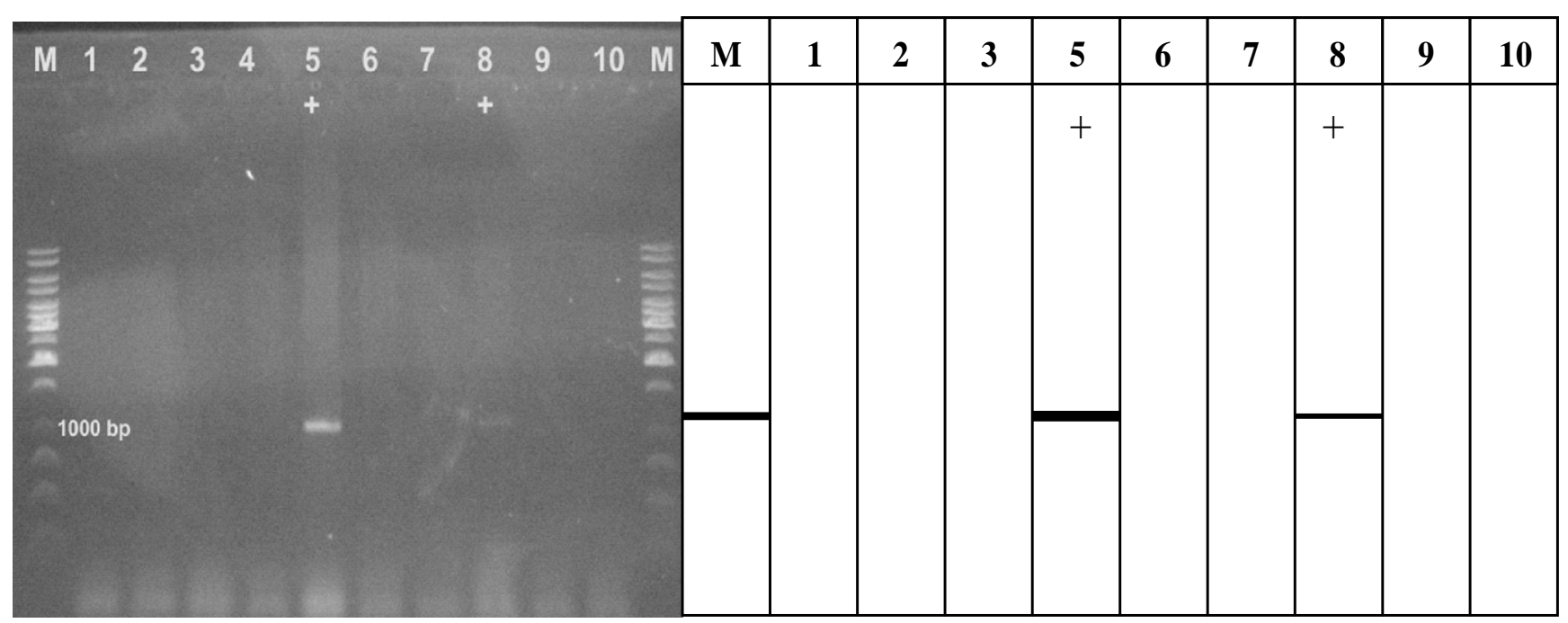

Gambar 2. Hasil PCR dengan menggunakan primer Primer forward (OI) Primer reverse (OI2c) pada isolat asal Konda. Kolom M (marker $1 \mathrm{~kb}$ ), kolom 1 (kontrol sehat), 2, 3, 4, 5, 6, 7, 8, 9, dan 10 sampel isolat CVPD. Sampel no 5 dan 8 positif terinfeksi CVPD

hasil PCR dari sampel tanaman sakit menggunakan primer OI1 (forward) dan OI2C (reverse) untuk strain Asia akan mengamplifikasi DNA sekitar $1160 \mathrm{bp}$. Dengan menggunakan primer yang sama Dwiastuti et al. (2003) berhasil menemukan ukuran fragment DNA L. asiaticum dari sampel isolat asal Jawa Timur.

\section{SIMPULAN}

Rata-rata jumlah tanaman yang menunjukkan gejala CVPD di Sulawesi Tenggara sebanyak 51,57\% di Kabupaten Kolaka dan 57,42\% di Kabupaten Konawe sampai dengan 69\%, jumlah terbanyak terdapat pada Kecamatan Ladongi, Kabupaten Kolaka dan Kecamatan Lalembuu 1, Kabupaten Konawe Selatan. Teknik PCR (polymerase chain reaction) berhasil mengamplifikasi fragment DNA bakteri $L$. asiaticum yang berukuran sekitar 1100 bp, namun demikian D. citri belum ditemukan di lokasi-lokasi kebun selama pengamatan lapangan.

\section{DAFTAR PUSTAKA}

Asaad M. 2001. Detection of Citrus Greening Organism, Liberobacter asiaticum, by Polymerase Chain Reaction. Thesis of Master of Agricultura Science, University Putra Malaysia.

Asaad M, Ramlan, Warda, Armiati \& Nurjanani. 2004. Indeksing Penyakit Utama Jeruk dan Upaya Pengendaliannya. Laporan Pengkajian BPTP Sulawesi Selatan.

Aubert B. 1992. Citrus greening disease, a serious limited factor for citriculture in Asia and Africa. International Congress, Acireale, Italy. International Society of Citriculture 2: 817820 
[BPTPH] Balai Proteksi Tanaman Pangan dan Hortikultura. 2004. Laporan Tahunan Balai Proteksi Tanaman Pangan dan Hortikultura, Sulawesi Tenggara.

[BPTPH] Balai Proteksi Tanaman Pangan dan Hortikultura. 2007. Laporan Tahunan Balai Proteksi Tanaman Pangan dan Hortikultura, Sulawesi Tenggara. Laporan Sementara.

Bove JM \& Garnier M. 1997. Rapid detection of $L$. asiaticum the causal agent of citrus Huanglungbin Disease (CVPD) in Bali, Indonesia. Report of 2 Consultancy North Bali Groundwater Irrigation and Water Supply - ALA/91/19.

Dinas Pertanian Kabupaten Luwu Utara. 2003. Data Luas Perkembangan Serangan Penyakit CVPD di Luwu Utara. Laporan Tahunan Diperta Luwu Utara.

[Dirtjenhorti] Direktorat Jenderal Bina Produksi Hortikultura. 2002. Agribisnis jeruk saat ini dan strategi pengembangan ke depan. Semiloka Nasional Pengembangan Jeruk dan Pameran Buah Jeruk Unggulan Bogor, 1011 Juli 2002.

Dwiatuti ME, Triwiratno A \& Anni. 2003. Pendeteksian dengan PCR (Polymerase chain reaction) keberadaan CVPD di Daerah SLPHT Jawa Timur. Hlm. 418-420 dalam: Prosiding Kongres XVII dan Seminar Ilmiah Nasional. Perhimpunan Fitopatologi Indonesia. Bandung, 6 - 8 Agustus 2003.

Garnier M, Jagoueix S, Cronje PR, Le Roux HF \& Bove JM. 2000. Genomic characterization of a liberobacter present in an ornamental rutaceous tree. Calodendrum capense, in Western Cape province of South Africa. Proposal a Candidatus liberobacter africanum subsp. capensis. Int. J. of Systematic and Evolutionary Microbiology. 50: 2119-2125.
Hoy MA \& Nguyen R. 1998. Citrus psylla. Here in Florida. http:// extlab7.entnemufl.edu/ PestAlert.

Jagoeuix S, Bove JM \& Garnier M. 1994. The phloem limited bacterium of greening disease of citrus is a member of the a - subdivision of the proteobacter. Int. J. of Syst. Bacteriology 44:379-386.

Jagoeuix S, Bove JM \& Garnier M. 1996. PCR detection of the two liberobacter species associated with greening disease of citrus. Molecular and Cellular Probes 10: 43-50.

Mead FW. 2006. Scientific name: Diaphorina citri Kuwayama (Insect: Hemiptera: Psyllidae). Department of Entomology and Nematology, University of Florida. http:// creatures.ifas.ufl.edu/citrus/acpsyllid.html diakses tanggal 3 Maret 2006.

Su HJ \& Hung HT. 2001. Detection of greening fastidious bacteria (GFB) causing citrus greening by dot hybridization and polymerase chain reaction (PCR) with DNA probes and primers pairs. http://www.agnet.org/library/ article/tn2001007.html diakses tanggal 5 Januari 2006).

Subandiyah S, Inanami T, Kondo Y, Kobayashi M \& Tsuyumo S. 2000. Comparison of 16 S rDNA and $16 \mathrm{~S} / 23 \mathrm{~S}$ intergenic region sequences among citrus greening organism in Asia. Plant Dis. 84: 15-18.

Triwiratno A \& Dwiastuti ME \& Supriyanto A. 1999. Quick detection of citrus greening by PCR method with spesific and universal primer. Ind. J. Biotech, June: 271-275.

Wirawan IGP, Sulistyowati L \& Wijaya IN. 2004. Penyakit CVPD pada Tanaman Jeruk. Analisis Baru Berbasis Bioteknologi. Direktorat Jenderal Bina Produksi Hortikultura, Departemen Pertanian. 